\title{
ORGANIZATIONAL IMPACTS OF THE ELECTRONIC PROCESSING SYSTEM OF THE BRAZILIAN SUPERIOR COURT OF JUSTICE
}

\author{
Christiana Soares de Freitas \\ Janann Joslin Medeiros \\ Universidade de Brasilia - UnB, Brasilia DF, Brasil
}

\begin{abstract}
This paper presents a study on the social and organizational impacts of the Electronic Processing System (EPS) implemented in 2008 by the Brazilian Superior Court of Justice (SCJ). This system is part of a wider transformation process involving the implementation of a new management model at the SCJ. The theoretical framework of the research conducted is based on the Technology Enactment Theory and other studies on the role of technological innovations in public organizations (Fountain, 2005; Freitas, 2012). Its main goal was to identify the most significant factors facilitating or inhibiting the innovation adoption. Results show different impacts of the EPS on professional groups and organizations. Political, cultural and economic aspects influence stakeholders' perceptions of the innovation, including its sustainability, time and cost saving that impact the rate of adoption and the realization of benefits both to users and the organization investing in its development.
\end{abstract}

Keywords: Innovation in the public sector, Technology Enactment Theory, Electronic Processing System, Judicial Processes, Brazilian Superior Court of Justice

\section{INTRODUCTION}

The Brazilian justice system has undergone significant changes in the last decades, in particular after the country implemented a new Constitution in 1988. These changes are part of an effort to transform the justice system into a more transparent, efficient and democratic one. Information and communication technologies (ICTs) are playing an important role in this process, fostering innovation in the public sector in an attempt to transform ponderous bureaucratic structures into more agile, result-andefficiency-oriented organizations (Guimarães et al., 2010; Almeida Filho, 2012).

Manuscript first received/Recebido em: 16/06/2013 Manuscript accepted/Aprovado em: 01/04/2015

Address for correspondence / Endereço para correspondência

Christiana Soares de Freitas, Professora Adjunta III Departamento de Gestão de Políticas Públicas/ Faculdade de Direito/ Universidade de Brasília (UnB) Campus Darcy Ribeiro / Asa Norte / Brasília, DF Email: freitas.christiana@gmail.com

Janann Joslin Medeiros, Professora Associada, Departamento de Administração/Faculdade de Economia, Administração e Ciências Contábeis/ Universidade de Brasília (UnB) Campus Darcy Ribeiro / Asa Norte / Brasília, DF - Email: janmedeiros@gmail.com

Published by/ Publicado por: TECSI FEA USP - 2015 All rights reserved. 
According to Fragale Filho and Veronese, "the key to understand the changes in the Brazilian judicial system is in the merging of new technologies with managerial arrangements consolidated by law-based standards" (Fragale Filho; Veronese, 2009: 136).

In this paper we examine the impacts of an innovation in the Brazilian court system that relies heavily on ICTs: the Electronic Processing System (EPS) of the Brazilian Superior Court of Justice (SCJ). This System was implemented at the Court in 2008 as part of a wider transformation process involving the implementation of a new management model with the goal of using technologies to eliminate the use of paper in judicial processes, thus facilitating the provision of faster, more effective and accessible justice to citizens of Brazil. The scale of the task undertaken is evidenced by the fact that during the year of 2008 there were 271.521 cases distributed to be judged and that by the end of this same year 251.022 cases were still open.

This article presents the results of research undertaken with two groups directly affected by the new practices developed by the Electronic Processing System in the SCJ: the professionals in the Department of Information and Communication Technologies of SCJ and the lawyers are users of the EPS. To identify possible changes in the organizations affected by the adoption of the Electronic Processing System, interviews were conducted with members of those groups, stakeholders directly involved or affected by these transformations. Specific goals included analyzing changes in practices and routines of the social actors involved. Data regarding structural transformations in the organization, including elements that tend to foster or inhibit the use of the Electronic Processing System and changes in the work routines of the lawyers were the focus of our analyses.

\section{THEORETICAL FRAMEWOK AND LITERATURE REVIEW}

Information and communication technologies have definitely been incorporated into the courts' practices (Fabri \& Contini, 2001; Fontainha, 2006). Technology Enactment Theory suggests that when technological resources are adopted there is a tendency to strengthen and reproduce social and structural mechanisms already institutionalized in the organization, and that this tendency affects the shaping of innovation itself. This theoretical approach emphasizes social and structural mechanisms in institutional relationships often shaping the use of innovation and holds that, despite the effort of some individuals in trying to incorporate technologies into their routines, innovations may conflict with the already established social practices and norms.

This theoretical perspective extends the basic principles of institutional theory in order to comprehend them in association with the logic of combining pre-established norms, values and social practices to the ones related to the frequent use of Information and Communication Technologies (ICTs). According to Fountain, "perceptions, interests and behavior are shaped by cognition, culture, social networks and the system of formal rules" (Fountain, 2005: 126, 2014).

Since the actors tend to shape their practices based on a system of preestablished practices and norms, the proposed technology is never implemented exactly as it was planned by their creators in its development. The tendency is that institutions will adopt a technology that is socially shaped after the conceived technology in the initial phase has been proposed. 
The technology enactment theory consists of three basic theoretical propositions, guided by the central principle of the theory which postulates that an adopted technology differs from the objective and initial technology proposed (Fountain, 2005: 128). The introduction of technological innovation tends to require constant adjustments in order to incorporate user demands, as can be observed frequently in the public sector.

The first proposition indicates that in organizations there is institutionalization, defined as the process of incorporating social patterns such as norms and practices into the structure and the functioning logic of these organizations. Selznick proposed the dispensability test to check whether one's norm or practice was already institutionalized (Selznick, 1948). It indicates the ease with which a certain practice or norm in an organization could be abandoned. If it is easy for the organization to dispense with it, this is an indication that the norm or practice is not institutionalized. Institutions arise from the social commitments of individuals that act in a given organization.

Technologies, in this perspective, are seen as capable of maintaining social networks through the legitimization of the set of practices and norms established in the organization (Fountain, 2005: 129). E-government tools and the engendered practices can be analyzed as elements that contribute to the institutionalization of specific norms. To analyze this context Fountain proposes the concept of digitally mediated institution which represents "a government organization characterized by a high degree of digital infrastructure and widespread use of digital applications and tools" (Fountain, 2014: 462). To analyze the political and social shaping of procedures, social norms and even the establishment of certain legal patterns, this digital infrastructure must be considered as one of the elements that characterizes government organizations nowadays.

The commitment that individuals make to the task of adopting an innovation is crucial for its success. As mentioned previously, the social commitments of individuals shape institutionalization, and this institutionalization, in turn, inhibits behavior. Thus the individual becomes inserted into a context of pre-established set of norms and may become hostage to their own history (Cotterrell, 2004; Selznick, 1948).

Another important aspect emphasized by the technology enactment theory is that the behavior of bureaucratic decision makers is shaped by four influences: cognition, culture, social structure and formal government systems.

The technology enactment theory further postulates that during the implementation of an innovation, social actors pursue their goals for recognition and power within the organization (Dawes, 2002; Fountain, 2001). Organizational actors tend to adopt technology to preserve social relationships or networks and maintain their performance in routines, scripts, frames and patterns that constitute the typical organized set of responses inside the organizations. Being the first one to know how to adopt a technology and deal with it can be seen as important nowadays for developing social capital and gaining recognition and status.

Related to this proposition is the concept of informational-technology capital, defined as a set of elements, both material and non-material, needed for an individual to become part of contemporary societies. There is a growing need to control and manage non-rival goods ${ }^{1}-$ most of them technological artifacts. In this scenario, there is an increase in the demand for specific knowledge that enables groups of actors to benefit from possible resources. This knowledge presupposes specific conditions of social, cultural and educational background of individuals. The more this capital exists as an

\footnotetext{
${ }^{1}$ Non-rival goods can be consumed or made use of by an individual without preventing simultaneous consumption or use by others.
} 
integral part of the habitus ${ }^{2}$ of an individual, the greater their opportunities for gaining knowledge and recognition. This new set of acquired elements is formed by three basic elements: specific knowledge, the necessary material apparatus to put into practice the knowledge learned and social conditions that make gaining of the required specific knowledge possible (Freitas, 2004, 2012).

The second proposition of the Technology Enactment Theory is based on the idea that an individual's action is restricted, constrained by the social structure of an institution, although action by the individual can sustain and modify such a structure (Fountain, 2005: 131, 2014). In other words, social structure will condition, to some degree, individual actions, although individuals can also develop specific attitudes and adhere to innovative practices based, for instance, on proposed new technologies in an institution. This tendency of some individuals to embrace innovation can therefore alter social structure.

The third proposition states that institutions influence the information technologies incorporated into their routine. At the same time, information technologies also influence the institution and its predominant organizational forms. Results of technology adoption are therefore multiple, unpredictable and indeterminate (Freitas, 2012). These results can be analyzed as a combination of technological, rational, social and political logics as shown in the following figure (Fountain, 2005: 127).

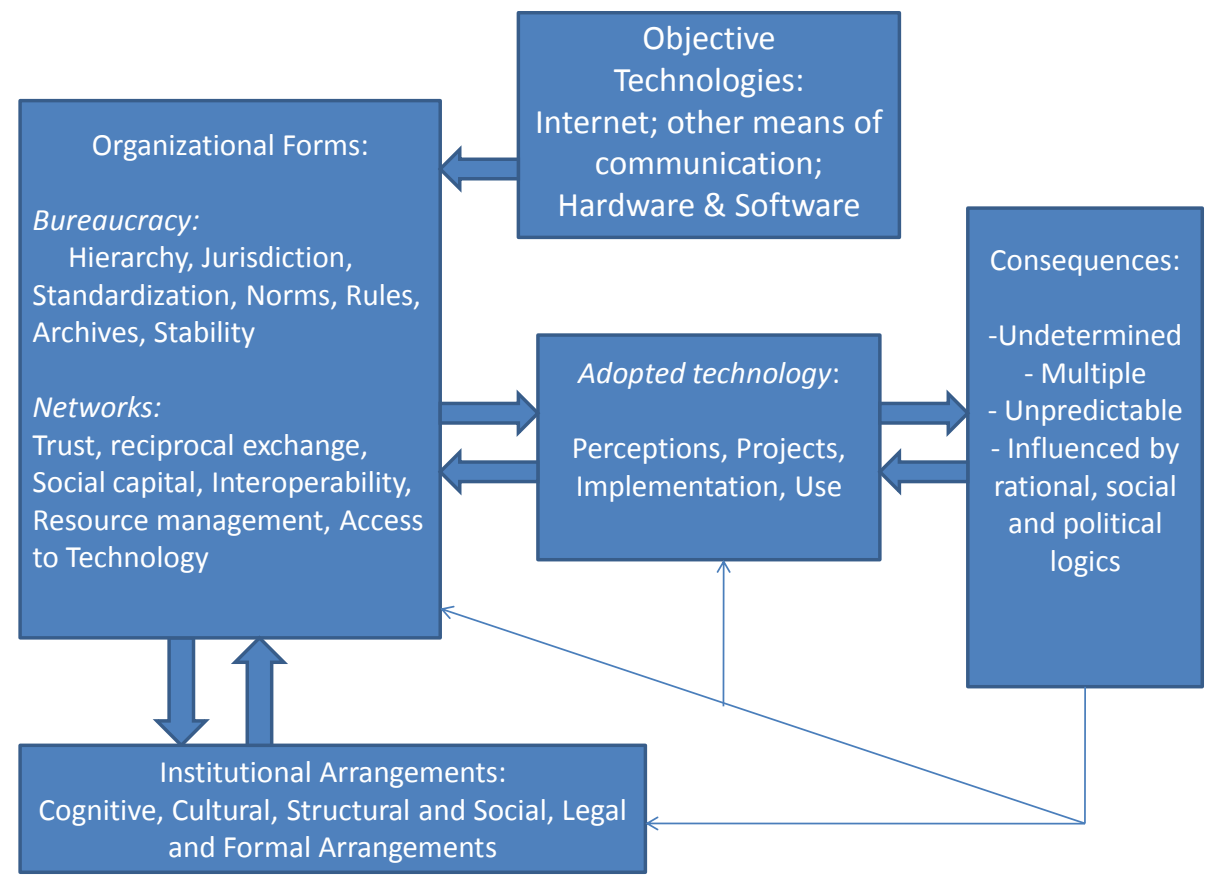

Figure 1: The analytical framework of the Technology Enactment Theory

Source: Fountain, 2005: 127

\footnotetext{
${ }^{2}$ The term habitus denotes a group of elements that are incorporated by individuals throughout their lives, guiding their actions and values; such dispositions are assimilated in accordance with social and historical living conditions. Each social arena provides its own group of elements, considered to be valuable to those individuals who participate in them (BOURDIEU, 1994).
} 


\section{METHODOLOGY}

The research was carried out in two phases and focused on two key groups involved in the innovation process. The first group - studied in the initial phase of the study - was composed of the information technology staff at SCJ responsible for designing and developing the Electronic Processing System (EPS). Research at this stage focused on the perceptions of this group regarding the creation and implementation of the EPS, especially related to how they understood their role in introducing and implementing the innovation and the impact of the innovation on the organization itself, on what had changed in terms of the legal framework and rules, hierarchical structure and work routines governing electronic processing as opposed to the processes on paper. We investigated, among other issues, whether the information technology staff, responsible for the design of the innovation, perceived this as being important for gaining social recognition and distinction.

The second phase of the study focused on users of the Electronic Processing System: twenty lawyers from private law firms that had a significant amount of cases being judged in the SCJ. During this stage, the aim was to identify the users' perceptions related to characteristics and consequences of the innovation studied such as the learning processes used by the users in adopting the innovation and factors facilitating or inhibiting its adoption.

Field research was carried out between August 2011 and September 2012. Qualitative data were collected by means of document analysis and in-depth interviews with members of the two groups of interest for the research. All of the six members that worked in the creation and development of the EPS were interviewed, after which a focus group was held with nine technologists involved in the initiative.

Lawyers interviewed were selected according to the amount of processes monthly registered from their respective States of origin in the SCJ and the frequency of their use of the EPS. Therefore, São Paulo and Brasilia - in the Federal District of Brazil - were the cities that had the most interviewed lawyers. The interviewees were from every region of the country, as seen in the figure below.

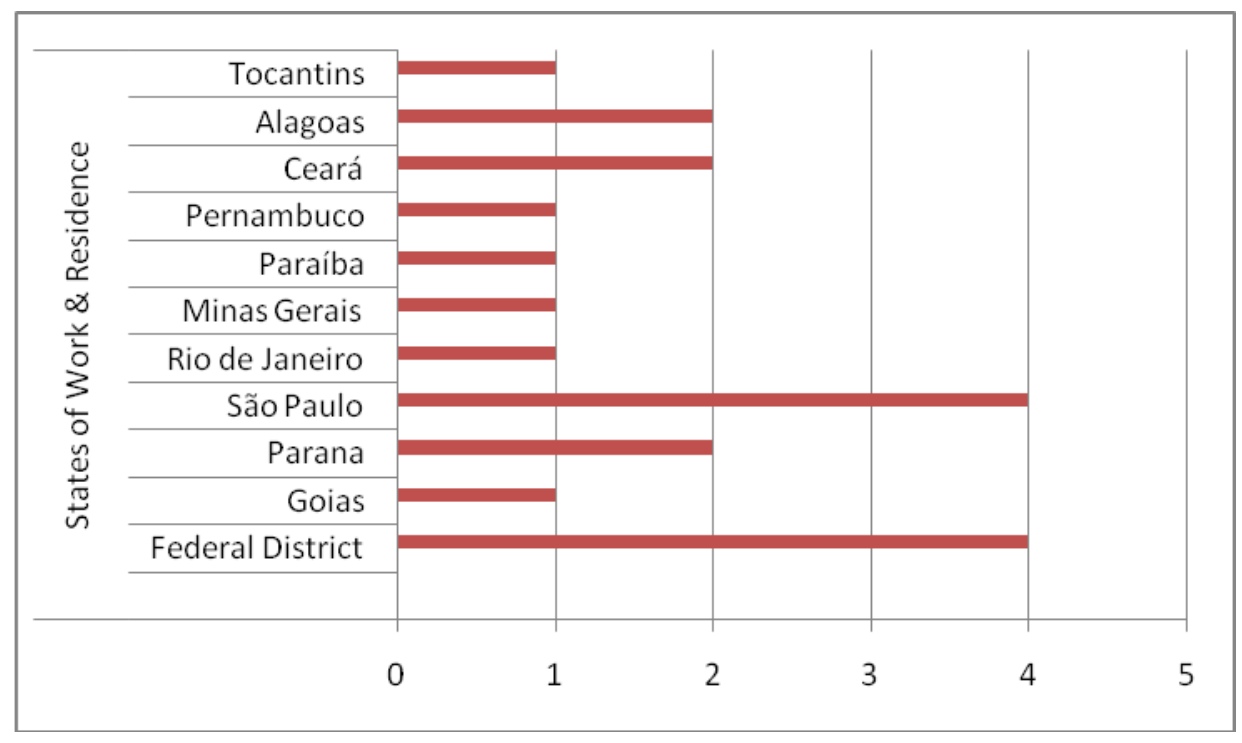

Figure 2: States of work and residence of the lawyers interviewed 
Of the lawyers interviewed six of them work in small law firms, nine in medium-sized ones and five in large firms ${ }^{3}$. Three of them were more than 50 years old, while 13 of them were from 40 to 50 years old. From the lawyers interviewed, four were less than 40 years old. Three lawyers were women - one from the State of Ceará and two from São Paulo.

Data were analyzed using content analysis techniques (Bardin, 2011) supported by the use of NVIVO 10 - software for qualitative data analysis. There were nine nodes or analytical categories sustaining the analysis. In the next figure the nodes are listed followed by the pertinent subnodes.

Node 1: Characteristics of the Respondents and their Organizations

Subnodes: Size of the Organization, Age range of respondents, Gender, Location (City and State of Brazil), Level of Informational-technology Capital

Node 2: Possible Changes in the Structure of the Organization

Subnodes: Horizontal Differentiation, Geographic Dispersion, Hierarchy, Legal Standards

Node 3: Changes in Routines and Responsibilities of the Staff of each Organization

\section{Node 4: Facilitators and Conductors of Use}

Subnodes: Perceived Ease of Use, Existing Skills to Use the Electronic System, Motivation, Political Relations interfering in the motivation to use - or not - the Electronic System (Subjective Norms), Cost Reduction for the Organization, Reduction of Time Spent Working, Perceived Usefulness

Node 5: Elements that inhibit the Use of the EPS

Subnodes: Complexity of the Electronic Process, Lack of Interoperability, Lack of Skills

Node 6: Means of Acquiring Skills to use the System

Node 7: Digital Certification

Node 8: Interorganizational Relations:

Law firm and Clients, Law firm and other Organizations, Law firm and other Law firms, Law firm and other Courts, Law firm and SCJ

Figure 3: Analytical Categories of the Research

In addition to the analytical categories presented, we looked for the discourse that suggests reproduction - or not - of pre-existing social and structural mechanisms that could be generating resistance to adopt the innovation. Also of interest were possible elements of the discourse regarding how the current scenario affected the technology design and implementation and for elements in the discourse revealing power relations or specific interests in the implementation and adoption processes.

\section{RESULTS AND ANALYSIS}

\footnotetext{
3 The reference for the definition of different sizes of lawyers' firms was taken from the concepts of the Brazilian Bar Association.
} 
The Electronic Processing System adopted by the Superior Court of Justice is one of the initiatives that guarantee the success of the new management model implemented by the organization based on the adoption of new information system components. This is an international tendency that can be analyzed not only in private organizations that are aiming at "enhancing their capability in order to survive in the competitions of the new century global market" (Karim, 2011: 459) but also in public organizations that have to become more efficient in order to provide adequate public services to citizens (Oskamp, Lodder, Apistola, 2004). In Brazil there are some efficient technological artifacts being implemented to achieve these goals in the judicial system, such as the e-Proc developed by the Regional Federal Court of the $4^{\text {th }}$ Region, one of the pioneers in the computerization of judicial processes (Silva, Spengler, 2013; Garcia, 2013b).

The research analyzed two different professional groups that are directly related to the EPS. While the Electronic Processing System implemented was seen mainly in terms of its advantages by the professionals that developed and worked on the implementation of the system; the lawyers that have to use it were not always so optimistic. Thus an initiative to promote the constitution of a digitally mediated institution is not always perceived as something positive by the ones who will be affected by it and this scenario will shape its acceptance and therefore the incorporation of the innovative feature in everyday practices of the organization players (Fountain, 2014).

The technologists of the SCJ tend to emphasize the advantages of changes that were - in 2008 - imposed by the Judge who at the time was the president of the Court. The development and use of the Electronic Processing System was an imposed decision that was incorporated by the group responsible for its creation, development and implementation. It is inferred that it then became of interest to this group to publicize positively what they had produced. Their status in the organization to a certain extent depended on the success of the innovation and its large-scale adoption (Meyer \& Rowan, 1977; Freitas, 2012).

Indeed, all the lawyers interviewed working in Brasilia had a significant acceptance of the new system. Such acceptance was observed not only with respect to lawyers from the national capital (Brasilia) but with respect to lawyers from state capitals such as Sao Paulo and Rio de Janeiro. However, this perception is not unanimous among all lawyers interviewed. The lawyers that tended to be more resistant to use it were those located in small cities or whose work took them to courts in small cities of the interior of Brazil.

There are several possible explanations for this. One is that the use of digital resources - such as tablets - in cities where the access to information technologies and modern artifacts is not very extensive and common, which can lead to some social constraints due to norms and practices already crystallized in organizations. One lawyer stated clearly that he felt uncomfortable using some artifacts in smaller cities because it is seen as "snobbish" or "elitist". Analyzing this fact using the lens of institutional theory, it can be inferred that the fact that some artifacts are not legitimized by the organization as usual or "normal" in common practices; they are expressed in attitudes towards the innovation with a tendency to view unusual practices as almost unacceptable, thus resulting in social pressures against their use.

The group of technologists that created the Electronic Processing System did not refer specifically to discrepancies related to its different levels of acceptance and 
institutionalization in different cities of the country. They did emphasize that they were in the process of diffusion of the innovation and that this process would take some time. Therefore some cities - especially the ones that were not state capitals - were still in the process of getting used to the changes required.

It can be observed the explicit difference in the perception of the distinct professional groups. What is seen as a transitory moment by the technologists is seen by - at least some of the lawyer-users - as a problem of acceptability of the innovation itself. The delay observed in a certain city compared to others in this extensively infrastructure adoption can hamper the process and limit the acceptability of the system.

A positive association was observed between age and resistance to innovation. All the lawyers interviewed that were more than fifty years old reported some difficulties in accessing or using the system. One of them had never used it. Specific levels of informational-technology capital of each interviewee were associated to their age. It was verified that the mentioned resistance to the system as an innovation was also conditioned by the level of informational-technology capital. All the lawyers that were more than 50 years old reported no domain at all or little domain related to information technology resources, reflecting on their capability of using the system.

The higher the informational-technology capital of a lawyer, the more likely they were to incorporate the new practices into their daily usage. On the other hand, a low informational-technology capital contributes to a lack of ability to manage the resources required to use the EPS and thus to lesser or non-use of the system. Another interesting observation is related to the fact that the majority of the lawyers interviewed had a moderate domain of IT resources as showed in the next figure.

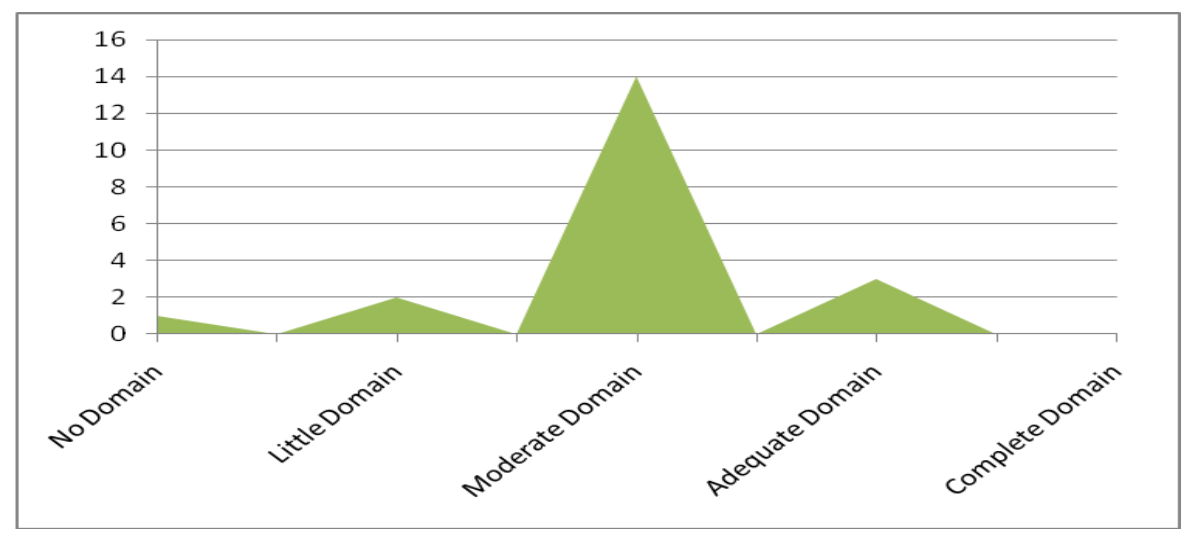

Figure 4: Levels of Informational-Technology Capital of the Attorneys interviewed.

That explains why they reported almost no difficulties in learning how to use the Electronic Processing System as it will be discussed in the next session.

\section{Knowledge acquisition}

Law firm employees did not attend special courses to learn how to manage or use the System. They learned with each other through learning by doing processes (Roussou, 2004). Nonetheless, 90\% of the lawyers interviewed affirmed that the knowledge they had in the information technology field was not sufficient to use all the 
features of the EPS. They had to develop new abilities and specific knowledge. This development, however, was not something that required great effort from them. From the ones who reported the need to gain new forms of knowledge, $89 \%$ pointed out that such gain was easy.

It was explained by the Court staff that the SCJ provides a complete guide to the use of their system by lawyers, explaining step by step all the required procedures. In several interviews this guide was cited as very useful and sometimes sufficient for learning how to use the system. Lawyers from the States of Alagoas and Paraná pointed out that another way of learning how to manage the Electronic Processing System was attending courses offered by the Brazilian Bar Association. However the interviewees stated that their demand for these courses was not high. The fact that lawyers consider the learning process to be relatively simple and that they learn by doing the tasks with colleagues in their own organizations can explain this low demand for specific courses.

\section{Impacts on routines}

Almost $70 \%$ of the lawyers affirmed that they now were working more than before, when there was no Electronic Processing System. The technological innovation allows them to take on a greater number of processes simultaneously. More judicial processes can be undertaken and accompanied in the same period of time. In addition, monitoring the status of processes is now easier not only for lawyers but for the staff of law firms. They report more agility and celerity in judicial processes and judgment of cases.

Two characteristics cited by all the lawyers regarding changes in routines were greater agility and celerity. Lawyers now have enough time to teach and transfer important skills to trainees, and they have, in turn, more time to learn. This enables comprehension in a more in-depth way of the logic that sustains not only the EPS but the judicial system in Brazil as a whole. The trainee has more time to learn the principles and practices of law as they can be involved in more intellectual aspects of the work as previously time-consuming bureaucratic and mechanical tasks are now unnecessary.

The Electronic Processing System was considered to contribute to efficiency, in that lawyers have access to information about changes in their processes the moment they occur. Interviewees reported that when a problem appears they can often solve it "in about three minutes" after they receive the notice informing them about it. $60 \%$ of the interviewees said that they reduced the number of tasks that previously had to be transferred to other persons of the organization, since it was now considered to be easier to do the task by themselves. At the same time, however, they pointed out that with the Electronic Processing System, work was in fact being transferred from the Court to the lawyers. Tasks previously carried out by the Court staff - such as making copies and putting together relevant documentation in the case of interlocutory appeals, for example, have now become the responsibility of the lawyers.

While the users tend to see quantitative changes in their daily work, the technologists of the SCJ perceive changes in the quality of the processes after the adoption of the EPS. Even though the quantitative aspect is recognized by technologists, they tend to emphasize the strategies they adopted internally to guarantee the quality of the whole system. Relationships with other actors and organizations affected by the 
changes had to be strengthened in order to create a positive atmosphere for the acceptance of the EPS.

\section{Factors facilitating the use of the EPS and its consequences}

A peculiarity of the Judicial System of Brazil is that each Court has its own Electronic Processing System. The lack of interoperability among the systems is a well known fact that has been discussed in several articles regarding this matter (Silva, Spengler, 2013; Fortes, 2012; Garcia 2013a). Despite the finding that some of these systems are not user-friendly, as will be discussed in the next section, the one developed by the Superior Court of Justice is positively perceived. The SCJ system was praised by $67 \%$ of the respondents as being the easiest program to use (and to learn how to use), unlike programs of other courts.

One of the components of the Electronic Processing System - the Diário da Justiça or official press - was specifically mentioned by $20 \%$ of the respondents as a way of contributing to more agile practices. Electronic publishing of the Diário da Justiça was one of the first technological artifacts adopted in the Court. According to statements from the interviewed technologists of the SCJ, this electronic publishing was an innovation that was introduced before the Electronic Processing System itself was put in place. Before this innovation, news with respect to decisions of the Court were sent to the National Press and then printed on paper. With the Diário da Justiça, the Superior Court of Justice began publishing same day information on its site, thus making it possible to access information on the same day it was published rather than the next day, as was previously the case.

A more practical and optimized routine was mentioned by $90 \%$ of the lawyers as an advantage of the EPS. One of the most cited elements motivating lawyers to use the EPS was the ease of working from any place at any time, resulting in efficiency gains.

From the lawyers interviewed, 95\% mentioned significant economies observed not only for the law firms but also for their clients with the introduction of the innovation. Previously there were high costs associated with copies and the outsourcing of various services related to delivering to and receiving documents from the courts, as well as with accompanying processes in Brasilia. The reduction of court visits, implying cost reductions for all the offices, especially the ones not located in or near Brasilia was cited by many.

It is interesting to observe that even though there was a reduction in the necessary time spent on each process, this has not been translated into less time working. As mentioned previously, lawyers tend to get more processes than before, while spending the same amount of time working daily. The difference is that they are now responsible for more processes simultaneously.

From the point of view of the technologists, certain characteristics have contributed to the adoption of the innovation by attorneys and within the SCJ itself. Since all the stakeholders can see the process online, there is no need for someone to have a physical possession of it - consequently stopping the judgment process while it is being read - and this has created a much more agile judging process. Besides agility, the other main characteristic cited was transparency. Before the EPS was introduced, a process was seen only by the interested party and by the minister (judge) designated to lead the judgment of that process. Since implementation of the innovation, any judge can see any process; and, with due observance of clauses safeguarding the secrecy of 
their access code, any lawyer with a digital certification can consult processes in which they have an interest as well.

\section{Inhibitors of the use}

All the users interviewed reported the need to learn new abilities to use the EPS. $24 \%$ of the lawyers stated that the absence of abilities, which should have been developed before they started to use the system, hampered its adoption in the beginning. Only one of the interviewees said that he still did not have the abilities and that he frequently had to turn to colleagues or to the Court for assistance to use the EPS.

For the interviewees that stated they did not have the necessary abilities when they began to use the system, its complexity and the potential for breaches of security in using it were cited as inhibiting factors.

From the perspective of the technologists there was ample preparation offered for those who had to start using it. In the beginning, according to the interviewees, there were three to four presentations a month for servants of the Court, other Courts in Brazil and law firms. Presentations were also made with a view to preparing staff of the Legislative and Executive branches of the Brazilian government. In the first year of implementation of the EPS, more than a dozen presentations were given with respect to how the system worked. This group reported that they had provided six weeks of training to more than 600 persons and mentioned proudly the visit of the Director of the World Bank with the express purpose of acquainting himself with the innovation. It is interesting to note that technologists tend to emphasize the positive effects of the transformations; besides, the success of the conceived system is crucial for their social recognition and prestige in the Court and in the other affected organizations.

There were other difficulties in using the system mentioned by the law firm lawyers. More than half of the interviewees (70\% of the respondents) mentioned the problem of the system not accepting a whole process in one transmission, if it is large in size. They often have to send a process in several parts, distributed among several messages, which can lead to other problems such as successfully sending some parts (messages) and not others. The instability of the system was also mentioned by $19 \%$ of the interviewees. These problems lead to others and the most important one is the delay in the development of the processes. This set of limitations was pointed out as a great inhibitor of the EPS use.

A disadvantage cited by $65 \%$ of the lawyers and technologists was the extreme dependence on the information technology system as a whole, including its infrastructure, internet functioning and the need for machines to be in good working condition.

Another serious problem mentioned is the inequality in terms of technological infrastructure in the various regions of the country. Of all the interviewees, $20 \%$ of the respondents pointed out this problem and affirmed that in their cities they can not count on the system functioning all day long, making it impossible to work full time with electronic processes.

Allied to this scenario there is the fact that many civil courts in Brazilian cities neither use digital processes nor the EPS. As an example, the lawyer from the State of Parana explained that "there are 27 civil benches in the capital city and only two of them use digital processes". The fact that many local courts still only accept physical (paper) processes makes changes more difficult to be implemented. The reasons for 
these limitations are the lack of infrastructure and local organizational cultures that simply do not take into account the possibility of using electronic processes.

Here again it is possible to see evidences for the theoretical proposition that preestablished sets of institutional norms of the institutions tend to interfere in the adoption of an innovation. Only when a certain individual or group in a specific institution starts to accept, incorporate and adopt new practices, the structure can then be changed.

The fact that each Court has its own specific norms and programs, each one with its own distinct operational system, was mentioned by all the respondents as a great inhibitor of the use of electronic systems of Courts in a general way (Davis, 1989). The lack of standardization or interoperability among the systems results in a great loss of time by lawyers since they have to learn how to deal with each system. This commonly means having to read a "two hundred page guide" specific for each Court. This fact was also stressed by the Information Technology Staff of the Court. Interoperability is therefore seen as an urgent and fundamental goal that must be achieved.

\section{Security of the Electronic Processing System}

According to the technologists, when the whole process is electronic there are no risks of losing fundamental evidences to certain cases. The process stays in a secure virtual space where all interested users, internal and external, can have access. According to the IT professionals of the Court, a reliable system to guarantee security was created based on the use of the digital certification for access. The technologists affirm that security was significantly improved with the Electronic Processing System. They argue that applications and processes are safely stored and crypto graphed. In their view, the digital system is safer because it stores the processes in a semi-public space where no one can remove a page of the process, for instance, and disappear with it. There is registration in the system of all users who access a specific process, whether they are internal or external users. To guarantee a high level of security, all the professionals that work with the EPS - especially those involved in problem solving and the creation of new artifacts for the system - are civil servants of the Court.

In contrast, lawyers, users of the system, do not perceive it as being as secure as IT professionals argue. Of the lawyers interviewed, 25\% mentioned possible actions of hackers, the vulnerability of the system and the possible risk of having their signature falsified. They also mentioned the need to acquire and frequently update equipment and programs as a drawback to using the EPS. In addition, all lawyers must renew their digital certification every three years. Despite these security issues, several advantages were pointed out by lawyers as well, such as celerity, ease, suitableness, cost reduction and efficient and concise use of resources.

\section{Impacts on the organizational structure}

The research investigated whether the innovation represented by the EPS caused changes to the structure of the affected organizations. There were no significant changes observed, whether by the Superior Court of Justice itself or the law firms. Even though work routines were changed there were no layoffs. Employees developed new capabilities and those unable to do so were relocated within the Court, assigned to other functions. 
With respect to the impacts of the innovation on the law firms that must interface with the SCJ, lawyers interviewed reported the adoption of new practices in their routines that did not imply significant transformations in their organizational structures. As in the SCJ, there were no layoffs and no hiring of new staff to learn how to deal with the system. The employees learned how to deal with it developing new abilities within the organization itself.

\section{Interorganizational networks}

The Superior Court of Justice collaborated significantly with other Courts especially state and regional courts - in the implementation process. Technologists from the SCJ developed and installed software applications to support the sending of processes from these courts in an electronic format. The SCJ also provided these courts with the necessary equipment. In the view of the technology staff, this collaboration was one of the elements that contributed to the success of implementing the EPS. SCJ staff members stayed for a time in each court to explain to their staff members how to use the Electronic Processing System. According to the technologists, the STJ assumed the responsibility of doing part of the job in view of the diversity of regions in the country and the overall complexity of this scenario.

Most of the communication that has to be established between the STJ and other Courts is developed in the electronic portal of the system ${ }^{4}$. Each Court has established a specific area to demand services, ask for support or report specific problems. As previously mentioned, the SCJ has established a special coordination unit to deal with these requests. In the view of the technologists, this digital interface of the SCJ has brought about closer relationships of SCJ with the state courts and federal regional courts. In addition, it has promoted a more transparent way of providing information and establishing communication. There is a common space in the interface where everyone can comment on topics of interest.

Cooperation agreements have also been established with other organizations of the Judicial System of Brazil, such as the National Justice Council, responsible for establishing norms and standards for the Brazilian judicial system, including technological standards.

The lawyers' perceptions of the efforts involved in disseminating the initiative can be seen as mainly positive. From these interviewees, only two respondents referred to the need for more cooperation between the Superior Court of Justice and law firms. The others saw the Court mainly as a public agent that tends to facilitate the adoption of the EPS by the involved actors.

Some changes were observed in the relationships established among law firms. Before the Electronic Processing System was implemented, a number of law firms in Brasilia were served as representatives of other firms from States of Brazil. They were fundamental as intermediaries between these firms and the SCJ. Relations established were seen as important to accelerate processes. Some law firms belonging to former judges of the SCJ in Brasilia were seen as essential for the success of some causes. Political factors were an important component of this scenario.

\footnotetext{
${ }^{4}$ The electronic portal of the SCJ that establishes communication with the other courts in Brazil is found at: $\underline{w w w . i s t j . j u s . b r}$
} 
Small offices that were specialized only in doing this intermediation disappeared or had to adjust their goals to the new reality, becoming specialized in other activities. It has been observed however that some medium size law firms have continued playing this intermediation role, establishing and maintaining contact with law firms from other cities, particularly those in which electronic processing is still not the norm, and supporting them in cases before the SCJ. It is perceived that there is still the option of establishing personal contact, since certain law firms and clients still prefer this means of communication. The interviewees that do not use the EPS (10\%) stated that they prefer to go to Court and establish personal contacts with clerks, judges and the STJ staff. One of the respondents affirmed the belief that these contacts assured celerity and special attention to the processes for which he is responsible.

The Electronic Processing System tends to make these personal contacts more difficult, tending to minimize the possibilities of expressing preferences with respect to the handling of processes before the Court. More attention is paid to procedures and norms. It can be inferred, from the evidence of the interviewees of this study, that more technical, impersonal - and less political - treatment is seen to be the tendency with respect to how processes are routed, analyzed and judged.

\section{CONCLUSIONS AND RECOMMENDATIONS}

A variety of perceptions of different stakeholders were clearly observed in the findings of this study. The technologists of the STJ, with a predominant technical background, tend to emphasize the positive impacts of the innovation and perceive the EPS as adopted almost universally. However, the users are not unanimous in confirming this perception. Whereas technologists see the EPS as more secure than the previous system, some users tend to focus on the problems that can still occur, fearing the possibility of actions from hackers, for instance. While technologists emphasize the transparency obtained with the System, users tend to highlight the increasing dependency on and need for good functioning of the overall EPS, including problemfree functioning of the internet and computers in operational conditions.

As mentioned in the theoretical framework, individual actions are constrained by traditional and already established norms and work routines in organizations. This fact could be observed in the Courts of the small cities that still do not have electronic processing and where the practices resulting from such processing are not institutionalized. They tend to resist using the artifacts of the System, constrained by cognitive, cultural and material factors that tend to shape the adoption of the innovation. This shaping will interfere, therefore, with the extent and degree to which the EPS will in fact be adopted by other professional groups and Courts in Brazil.

While social structure is constraining, it is possible for individuals that favor innovation initiatives to slowly change previously hegemonic pre-established and institutionalized norms and practices. This phenomenon can be clearly perceived in the case of the technologists of the SCJ who embraced the transformations required and initiated a complex process of developing and disseminating the Electronic Processing System that involved establishing collaborative relations with other organizations and the implementation of organizational changes to support the innovation in focus.

According to the users of the EPS, the major factor limiting greater use of the innovation is the lack of interoperability among different electronic systems in the 
country. Interoperability is therefore one of the crucial and most important issues to be considered, whose implementation is seen as both fundamental and urgent.

The lack of adequate technological infrastructure - especially in some regions in Brazil - is also a significant limitation to the adoption of the Electronic Processing System. Further studies could focus on this issue and investigate in detail the specific conditions of all States of the country and the impacts of this situation on the Judiciary System of Brazil.

\section{REFERENCES}

Almeida Filho, J. C. A. (2012) Processo Eletrônico e Teoria Geral do Processo Eletrônico. A Informatização Judicial no Brasil. 4. ed. Rio de Janeiro: Forense.

Bardin, L. (2011). Análise de Conteúdo, São Paulo: Edições 70.

Cotterrell, R.; Selznick, P. (2004). Selznick Interviewed: Philip Selznick in Conversation with Roger Cotterrell. Journal of Law and Society, 31 (3): 291-317.

Davis, F. D. (1989). Perceived usefulness, perceived ease of use, and user acceptance of information technology. MIS Quarterly, 13(3), 319-341.

Fabri, M.; Contini, F. (Ed.). (2001). Justice and technology in Europe: How ICT is changing the judicial business. The Hague, The Netherlands: Kluwer Law International.

Fontainha, F. C. (2006). A informatização da vida e dos tribunais no Brasil. Paper presented at the XIV Congresso do CONPEDI, 2006, Fortaleza (CE). Retrieved April 21, 2008, from http://conpedi.org/manaus/arquivos/Anais/Fernando\%20de\%20Castro\%20Fantainha_Ef etividades $\% 20 \mathrm{e} \% 20$ Garantias $\% 20 \mathrm{do} \% 20$ Processo.pdf.

Fortes, R. C. (2009) Informatização do Judiciário e o processo eletrônico. Jus Navigandi, Teresina, ano 14, n. 2374. Disponível em: <http://jus.com.br/revista/texto/14101>. Acessado em 21 fev. 2012.

Fountain, J. (2005). Construindo um Estado Virtual: tecnologia da informação e mudança institucional. Brasilia: ENAP.

Fountain, J. (2014). On the Effects of e-Government on Political Institutions. In: Handbook of Science, Technology and Society, edited by D. Kleinman and K. Moore. London: Routledge.

Fragale Filho, R.; Veronese, A. Electronic Justice in Brazil (2009). In: E-Justice: Information and Communication Technologies in the Court System, edited by A.C. Martínez and P.F. Abat. London: Information Science Reference/IGI Global, p. 135151.

Freitas, C. S. (2004). O capital tecnológico-informacional. Estudos de Sociologia. Araraquara: Ed. UNESP, vol. 9, n. 17, p. 115-132.

Freitas, C. S. (2012). O Software Público Brasileiro: novos modelos de cooperação econômica entre Estado e Sociedade Civil. Informação \& Sociedade (UFPB. Online), v. 22, p. 99-113.

Garcia, S. R. T. (2013a) Informatização e prestação jurisdicional: desafios e perspectivas. Revista de Doutrina da 4 ${ }^{\mathrm{a}}$ Região. Porto Alegre, n. 11, maio 2006. 
Disponível em <http://www.revistadoutrina.trf4.jus.br/index.htm?>. Acessado em 01 maio 2013.

Garcia, S. R. T. (2013b). Informação Fidedigna - Pje necessita de gestão mais transparente e democrática. CONJUR, Revista Consultor Jurídico. 11 de outubro de 2013. Disponível em: <http://www.conjur.com.br/2013-out-11/tejada-pje-necessitagestao-transparente-democratica>. Acessado em 07 nov. 2013.

Guimarães, T; Odelius, C; Medeiros, J; Santana, J. (2010). Management Innovation at the Brazilian Superior Tribunal of Justice. The American Review of Public Administration, 1-15, London: Sage.

Karim, A. J. (2011). The Significance of Management Information Systems for Enhancing Strategic and Tactical Planning. JISTEM Journal of Information Systems and Technology Management. Vol.8, No.2, p. 459-470.

Meyer, J.; Rowan, B. (1977). Institutionalized organizations: formal structure as myth and ceremony. American Journal of Sociology, 83, p. 340-63.

Oskamp, A.; Lodder, A. R.; Apistola, M. (Ed.). (2004). IT support of the judiciary: Australia, Singapore, Venezuela, Norway, The Netherlands and Italy. The Hague, The Netherlands: TMC Asser Press.

Roussou, M. (2004). Learning by Doing and Learning Through Play: An Exploration of Interactivity in Virtual Environments for Children. ACM Computers in Entertainment, Volume 2, Number 1, January.

Selznick, P. (1948). Foundations of the Theory of Organization. American Sociological Review, 13 (1): 25-35.

Silva, Q. C. S.; Spengler, F. M. (2013). O processo eletrônico no Brasil e a experiência prática do Tribunal Regional federal da $4^{\mathrm{a}}$ Região. In: Derechos Humanos y Protección de datos personales en el Siglo XXI. Edited by Alvaro Sanchez Bravo. Espanha: Punto Rojo S.L., p. 79-112. 